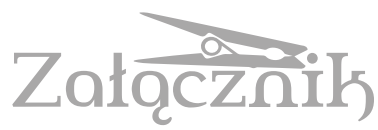

DOI 10.21697/zk.2020.7.02

\title{
GA AMONG GIANTS. GANS'S SCENE OF LANGUAGE AND CULTURE ORIGIN IN REFERENCE TO CASSIRER'S AND HEIDEGGER'S VISIONS OF THE HUMAN
}

MAgdalena Z ŁoCKA-DĄBROWSKA

Wydział Nauk Humanistycznych UKSW

Faculty of Humanities,

Cardinal Stefan Wyszynski Uniyersity in Warsaw

m.zlocka@uksw.edu.pl

ORCID: 0000-0003-0136-0764

The present disparity of visions of the human inspires us to search for one that captures culture as the human's holistic and universal property and unique characteristic. Our approach connects an anthropological inquiry with an interpretation of philosophical discourses as a series of concepts of consecutive order, where one gradually replaces the other, yet they meet at a crossroads. In particular, we will address two dominant models of thoughts on the human and its being, with a third one - the mediator - whose position in between we will discuss. We read the first model, by Ernst Cassirer, as contained in a phenomenology of symbolic forms, understood as a system of symbolic representations of being on a metaphysical base. The second model, proposed by Martin Heidegger, refers to the idea of Being ${ }^{1}$ as a system of self-presentation; no longer, however, on a metaphysical base. We submit, that the third model, formed by Eric Gans's theory of Generative Anthropology (GA) ${ }^{2}$ - a vision of origin of 'human as human', also in a non-metaphysical sense - is to be placed at the junction of the two former ones.

1 The English term 'Being' is here the equivalent of Heidegger's German original 'Dasein'. The concept of Being, appears usually with a capital 'B' as opposed to beings. In some translations, however, it also appears with a small ' $b$ ' and its distinction with beings is recognized from the context.

2 GA, although not yet named by this term, first appeared in The Origin of Language. A Formal Theory of Representation (1981), where Gans formulates his 
So we have two intricate philosophical systems of the past, explaining and defining the human and its being, and one actual anthropological approach, focused on expounding the origin of representation to define the human condition. Studying the contemporary concept of GA and the older visions by Cassirer and Heidegger may render the past present. Cassirer's symbolic forms and Heidegger's unwavering question of Being constitute a reference point for the entire discourse on GA, which encroaches, we argue, upon human ontology. For, we understand GA not only to explain the meaning, but also the structure of being of the human, based on the principle of causality. Thus, GA, an originary hypothesis, a heuristically efficient nominalist model, aspires to become an applied ontology, equivalent to „making the effort to conceive the human" ${ }^{3}$ in a consistently realist manner.

At present times, in a world of domination by micro-ideas, unlike Cassirer's and Heidegger's systems, GA belongs to a few overall visions

initial hypothesis that man originated together with a language in a memorable event. In subsequent books, beginning with The End of Culture, Gans uses the term 'Generative Anthropology', to reveal the newly discovered mechanisms and properties of the scene of origin. In the End of Culture. Toward a Generative Anthropology (1985) and later, in Science and Faith (1990), he discusses the cultural and religious consequences of the originary hypothesis. In Originary Thinking (1993), Gans pursues an exploration of the philosophy of language, ethics, religion, theory of discourse and esthetics. In the next volumes and articles, he broadly and systematically widens GA's comprehension of these scientific areas. Gans's most important books on GA, in a chronological order, are as follows: E. Gans, The Origin of Language. A Formal Theory of Representation, Berkeley - Los Angeles - London 1981 (2019); idem, The End of Culture. Toward a Generative Anthropology, Los Angeles - London 1985; idem, Science and Faith. The Anthropology of Revelation, Savage 1990; idem, Originary Thinking: Elements of Generative Anthropology, Stanford 1993; idem, Signs of Paradox: Irony, Resentment, and Other Mimetic Structures, Stanford 1997; idem, The Scenic Imagination. Originary Thinking from Hobbes to the Present Day, Stanford 2008; idem, A New Way of Thinking: Generative Anthropology in Religion, Philosophy, Art, Autora 2011; and dozens of articles published to date. First of all see the articles in: „Anthropoetics. Journal of Generative Anthropology”, www. anthropoetics.ucla.edu; and further "Chronicles of Love and Resentment”, www. anthropoetics.ucla.edu/views/ [accessed 23.03.2020].

3 Idem, Originary Thinking..., op. cit., p. VII. 
that offer an intriguing proposal of understanding the ontology of language and culture as the founding of human representation. GA creates a systematic account, a system of knowledge, related to its origin. As such a vision, GA needs to be situated within the Western philosophical tradition. Gans himself confirms that „the greatest intellectual affinities/rivalries of GA as a way of thinking are undoubtedly with philosophy". In a sense GA is deeply inspired by past philosophy (metaphysics) and its failure to do anything but „seek to fix a point of origin, an endeavor condemned to endless repetition where »origin « is "always already" inhabited by the search for itself" Gans presents GA as a 'minimal hypothesis', aiming to touch 'untouchable questions' and places a simple hypothesis amid distant philosophical contexts, ranging from antiquity to Thomas Hobbes, through Étienne Bonnot de Condillac, Jean-Jacques Rousseau, Giambattista Vico, Johann Gottfried Herder to Immanuel Kant ${ }^{7}$. But he looks for contexts of GA quite broadly and also searches for references in more recent philosophical thought, such as that of Friedrich Schiller ${ }^{8}$, Friedrich Nietzsche ${ }^{9}$, Max Scheler ${ }^{10}$ or contemporaries like Jean Paul Sartre and Jacques Derrida ${ }^{11}$. Considering Gans's emphasis on philosophical perspectives, we got interested in relating his ideas to the two giant thinkers mentioned in the first paragraph.

Although Cassirer is an advocate of the theory of representation ${ }^{12}$, so basic and important in the GA formula, mentioned above as constituting the 'human as human', Gans does not engage in an open discourse with Cassirer's thought. By contrast, he refers directly to Heidegger and what he

${ }^{4}$ Idem, A GA Cogito and other philosophical reinterpretations, "Chronicles of Love and Resentment", No. 63, 28.09.2019, http://anthropoetics.ucla.edu/views/ vw633/ [accessed 9.03.2020].

${ }^{5}$ Idem, The Origin of Language..., op. cit., p. IX..

6 See: idem, The End of Culture..., op. cit. p. 19-35.

7 See: idem, The Scenic Imagination..., op. cit.

8 See: idem, Originary Thinking..., op. cit., p. 134, 153.

9 Ibidem, p. 109-111, 141-142, 200-201.

10 Ibidem, p. 159, 182.

${ }^{11}$ See: idem, The End of Culture..., op. cit., p. 10, 37, 68, 69, 70.

12 For Cassirer that 'representation' is a relation internal to consciousness is, as we'll see, central to Cassirer's model. 
terms his 'seminal texts'. In a Chronicle of Love and Resentment entitled On 'Being and Time', he acknowledges having been impressed by Heidegger's „impatience with ontic or empirical explanations of the human”13 and recognizes parts of Heidegger's thought on being, thinking and signification as an inspiration for his own reflection. Mainly this relates to a number of chapters from Originary Thinking and Signs of Paradox ${ }^{14}$. In the text On 'Being and Time' he claims outrightly that GA grew up as a response to Heidegger's 'ontological turn', and he is convinced of a possible resource of anthropological content that can be uncovered there ${ }^{15}$. Gans also considers the essential solipsism of the phenomenological method to be a central issue. The assumption that the other's mind can't be experienced by us directly and that each individual mind generates its ontology based on existential experience of the world leads him to Husserl's view on the contingency of other people in reference to one's own mental universe. This idea directs Gans to contrast Husserl with Heidegger who notes the existence not only of other individuals but also of 'being-with' [Mitsein $]^{16}$ and 'coexistence' $\left[\right.$ Mitdasein ${ }^{17}$. However, according to Heidegger, due to the existence of society or community we are not led to Being, but rather we are seduced with the thought of losing the self in a mimetic crowd, in a crowd understood as 'people' [das Man] $]^{18}$. But as Heidegger never follows Durkheim and does not go from society to Being, Gans believes that Heidegger precedes GA in demonstrating the limits of empirical anthropology, and he thinks that they cover a similar ground.

13 See: E. Gans, On 'Being and Time', „Chronicles of Love and Resentment”, No. 226, 20.01.2001, http://anthropoetics.ucla.edu/views/vw226/ [accessed 17.03.2020].

14 See note 2.

15 See: E. Gans, On 'Being and Time', op. cit.. It should be added that, later on, researchers close to Gans also compared and moved GA closer to Heidegger's thoughts (See: M. Ludwigs, From de Man to Gans: The Return of the Referent, "Anthropoetics” 2018, Vol. XXIII, No. 2; eadem, Three Gaps of Representation / Three Meanings of Transcendence, „Anthropoetics” 2010, Vol. XV, No. 2).

16 E. Gans, On 'Being and Time', op. cit.

17 Ibidem.

18 Ibidem. 
Having briefly considered Gans's position, let's note that the approaches of Cassirer and Heidegger have been extremely influential in philosophical inquiry and were highlighted by the famous dispute at Davos ${ }^{19}$, and formed contemporary thinking since the first half of the 20 th century ${ }^{20}$. These two rivalling philosophical systems contending for a dominant position, than could be mapped within Gans's core idea, the so-called 'scene of origin'21, along with its metaphorical meaning. We will find in this scene the announcement of two conceptualizations of the world that prepare us for 'a new way of thinking' ${ }^{22}$, a new heuristic process, which proves powerful enough to transcend previous presuppositions. The Cassirer's rational spontaneity confronts Heidegger's concept of Being, resulting in a collision between idealism and existentialism. In this sense one may argue that Gans's theory participates in their discourse by his efforts to propose an understanding

19 See: P. Gordon, Continental Divide: Heidegger, Cassirer, Davos, Cambridge (Mass) 2012.

20 Let us just recall Swiss Davos and its unforgettable debate of 1929. The dispute gained a mythical status, as an unprecedented event, a turn in $20^{\text {th }}$ century continental thought, where the confrontation between the two philosophical celebrities reached public fame. Although its main issue was 'to be Kantian or not to be', we may consider it as a pretext to speak about several contexts of the models of the human proposed by Cassirer and Heidegger, with the entire background of the schools of thought they represented, but also as a turning point for the next models of the human. During the actual debate, the most fundamental questions were asked, essentially referring to what it means to be human, related to objectivity, truth, finitude, and also, what is most important to us, culture. One side of the discourse was performed by Cassirer, a creative adept of Kant, and the other by Heidegger, an intriguing de-constructor of previous concepts of the human. The common starting point of these thinkers of the German existential crisis also constituted the basic context for further debates on neo-Kantianism, phenomenology, existentialism as well as a broad anthropological understanding of the human, including the legitimacy of defining the human in relation to the natural and social setting.

${ }^{21}$ Gans formulates the original joy of the scene of origin, first in the mentioned The Origin of Language. In the next books, he extends all the aspects raised in his first work by adding contents that together form a complex theory.

${ }^{22}$ See: E. Gans, A New Way of Thinking..., op. cit. 
of the human, placed between the idealism of human intentionality one may recognize in the scene $e^{23}$ and the existential pragmatism of its results the system of representation and its abilities to regulate human life.

Thus GA brings in alternative perspectives, as Gans speaks of 'human origins' based on the origin of language, which constitutes, we may say, the ontology of human representation. According to Gans, representation is by no means restricted to language, yet no systematic theory of representation can start with something other than language ${ }^{24}$. Philosophers from time immemorial have formulated hypothetical 'scenes' of the birth of a language $e^{25}$, which Gans considers as the origin of representation, the primal moment for humanity. But only his theory speaks of the original 'scene' of language or of a cultural phenomenon that is both collective and evenemential ${ }^{26}$. The appearance of the first sign, which also means the appearance of language and then of culture, implies the constitutive forms of the transition of being to an anthropological dimension ${ }^{27}$. Gans decisively claims that the human is constituted in a series of scenic events $\mathrm{s}^{28}$. The scenic event, in general terms, as a simultaneous presence of situational components building human representation, is far from a simplified, scenic theory of the origin of language such as those already known since antiquit $^{29}$ or even from being a performance theory, with its emphasis process

${ }^{23}$ See: M. Złocka-Dąbrowska, Generative Anthropology's Scene of Origin in Cognitive and Axiological Contexts, „Anthropoetics” 2019, Vol. XXIV, No. 2, http:// anthropoetics.ucla.edu/ap2402/2402mzd/ [accessed 23.03.2020].

24 E. Gans, The Origin of Language..., op. cit., p. 29.

25 See above all: H. Steinthal, Geschichte der Sprachwissenschaft bei den Griechen und Römern, mit besonderer Rücksicht auf die Logik. Berlin 1890-1891; Language. Companions to Ancient Thought, Vol. 3, ed. S. Everson, Cambridge 1994; Language and Learning: Philosophy of Language in the Hellenistic Age (Papers presented at the Ninth Symposium Hellenisticum, held in Haus Rissen, Hamburg, Germany, 23-28 July 2001), eds. D. Frede, B. Inwood, Cambridge 2005.

26 E. Gans, The Origin of Language..., op. cit., p. X.

27 Ibidem, p. 71.

28 Idem, The Scenic Imagination..., op. cit., p. 2.

29 Idem, The Origin of Language..., op. cit., p. X. 
and action being constitutive of language ${ }^{30}$ and culture ${ }^{31}$. In the GA scene, Gans rather shows a primordial and universal model of the human and its being, that is humanity's basic way of presence in the world, from the ground $u^{32}$. This model presents a coexistence in time of humans qualified in a specific way focused on objects of common interest, as the sine qua non condition of the appearance of language and its theories ${ }^{33}$. Let us then ask what this model looks like.

\section{GANS'S SCENE OF ORIGIN}

The scene of origin is formed by a group of proto-humans surrounding the so-called central object, which is an animal hunted as prey, the object of human mimetic desire ${ }^{34}$ in its simplest version: it is an object of appetite. The object is initially a victim ${ }^{35}$, but we may also think of any other desirable object one would like to eat or possess. Seeing the object, one member of the group surrounding it makes a gesture of pointing ${ }^{36}$, originally an aborted gesture of appropriation, whose parallel effect is the emission

${ }^{30}$ See: D. Hymes, Language in Culture and Society: A Reader in Linguistics and Anthropology, New York 1964.

${ }_{31}$ See: V. Turner, The Anthropology of Performance, New York 1988; R. Schechner, Performance Theory, London - New York 2003.

${ }^{32}$ E. Gans, The Origin of Language..., op. cit., p. 111.

33 Ibidem, p. 3.

34 An idea of mimetic desire is present in Gans' concept of GA, thanks to its creator, Rene Girard and his mimetic theory. Gans includes elements of mimetic theory to his model, beginning in the mentioned The Origin of Language up to The Girardian Origins of Generative Anthropology (Imitatio / Amazon Digital Services, 2012), but this subject will not be discussed here now.

35 Gans bases his ideas on the mimetic theory of René Girard, in which the victim has a central meaning as a member of the group; but this topic exceeds the problems discussed here. See: R. Girard, La Violence et le sacré, Paris 1972; idem, Des choses cachées depuis la fondation du monde, Paris 1978.

36 One may interpret Gans' pointing as referring to gestural theories, but only when it is reduced to evolutionary theories of language origin, by eliminating the communal, evenemential, cognitive and causal (deferral of violence) associations of GA. 
of a $\operatorname{sign}^{37}$. This ostensive sign appears within „a communicative context defined by the presence of interlocutors one to the other", where designation and the communal presence constitute language $e^{38}$, whose appearance addresses a crisis of the group. That is why we cannot forget that the human from the scene is equipped with all his existential properties - not only appetite, but also rivalry for objects, which implies a potential for violence, a probable conflict and a propensity for crisis. They are all constantly present - latent, but operative and contingently capable of being deferred ${ }^{39}$ by appearance of the mentioned sign, language, and through it - all other cultural representations that suffice to defer the appropriation of the object and thus to avert the violence, conflict and crisis ${ }^{40}$. It should be added that the emission of a sign is 'an aborted gesture of appropriation't1 ${ }^{31}$ oriented to defer violence, with the object of deferral its referent. The deferral of potential violence is the purpose of representation. Violence is averted by fear for the future based on memory of the 'immediate past ${ }^{32}$ as well as the need of a deferral of desire for the mentioned object. The designation process de-

37 Sign theory has been known in linguistic studies already since Ferdinand de Saussure (Course de linguistique générale, Lausanne - Paris 1916), but also thanks to Hermann von Helmholtz and his sign theory of perception which Cassirer speaks about (E. Cassirer, The Philosophy of Symbolic Forms, Vol. I: Language, transl. R. Manheim, preface and introduction Ch.W.. Hendel, New Haven 1953, p. 75) as well as thanks to the work of Charles S. Peirce (The Essential Peirce. Selected Philosophical Writings. Vol. 1-2, Bloomington - Indianapolis 1992-1998). It should be added that Gans' notion of 'sign' only repeats de Saussurian's terminology, but not its concept. See the next parts of this text.

38 E. Gans, The Origin of Language..., op. cit., p. 38

39 Gans explains that: „Deferral is the translation of différance, a neologism coined by Jacques Derrida that uses the double meaning of the French verb différer (both 'differ' and 'defer') to express the non-co-presence of the different significations that Saussure had seen as opposing each other in an atemporal structure" (E. Gans, The End of Culture..., op. cit., p. 18 note 5). In addition, it is worth adding Gans' explanation that "The scene of representation differs from the real precisely because it defers the real, which is to say, the appetite" (ibidem, p. 37).

40 Ibidem, p. 41.

41 Ibidem., p. 55.

42 Idem, The Origin of Language..., op. cit., p. 39. 
scribed here is not born as „, a single and arbitrary association of a sign with an object"43. Gans says that the act of designation is primarily of a peaceful nature and the result of an equilibrium between the violence and of the act of appropriation of the object ${ }^{44}$. The sign itself does not intend to relate to the world directly, but through designation, which results in formal product which cuts off from the possibility of attaining the object. Thus, the sign becomes a product of a formal consciousness, a form that protects humans against the violent rivalry in the real gesture of appropriation of an object ${ }^{45}$.

Gans's scene of the origin of language and culture constitutes the primary human response to the world, a constantly repetitive moment of existence, an essential form of being. This human scene, we may say, has a meaning linking it to Cassirer's and Heidegger's philosophical models. To demonstrate their interrelationship, let us first look at some assumptions of Cassirer's and Heidegger's discourse, while still remembering that GA aspires to become an applied ontology. This ontology, while encapsulated in a concept of language and culture origin equivalent to, as Gans calls it, 'an origin of a human' and origin of representation, is somewhat similar to Cassirer's concept of the animal symbolicum, comprehended as a symbolic system, insofar as both Gans and Cassirer think in terms of a universal philosophy of cultural sciences.

\section{GANS AND CASSIRER}

Gans's model of the scene of origin focuses on the appearance of a sign, and thus, language and culture. Cassirer composes conditions of the possibility for the 'fact of culture', but of its richness and diversity rather than its origin. Cassirer's conception of a human being is of a sign user, but in the context of systems of human expression, in relationships with the world. Cassirer's sign is not a mere accidental cloak of the idea, but it is necessary, essential and functional. It serves not only to communicate a complete and

43 Ibidem.

44 Ibidem. This description constitutes a short extract from the whole GA theory, the complete discussion of which exceeds the scope of the issue raised in the article.

45 Idem, Signs of Paradox..., op. cit., p. 30. 
given thought content but is an instrument by means of which this content develops and fully defines itself ${ }^{46}$.

In turn, Gans assures us repeatedly that the origin of a sign is designation, signification, and deferral ${ }^{47}$, all referred to the system of representation, where representation may remind us of the symbolic sphere. By representation, Cassirer means a relation internal to consciousness ${ }^{48}$, which, we argue, plays a decisive role in 'scenic production of signs'. Therefore, we may assume that Gans's representation corresponds to Cassirer's collection of symbols. Nevertheless, GA, in the model presented above, does not use the concept of a symbol - even the term itself does not figure significantly in the early pe$\operatorname{riod}^{49}$. However we could imagine the possible juxtaposition of the sign and the symbol, which would remind us of the fundamental effect of the scene mentioned, while being aware of the differences between the authors' views as indicated by their respective conceptual choices. For Gans, sign is, and symbol would be, as language - representational as the first, primordial, basic and indispensable form of human interaction ${ }^{50}$.

Cassirer's core idea presents a model of the symbolic organization of the world, a general theory of cultural forms. This model, placed in the context of a comprehension of human language and culture, is best known from his Philosophy of Symbolic Forms and its first volume entitled Language ${ }^{51}$, which itself indicates Cassirer's favorite area of reflection. For Cassirer, language is an ordering, dynamic principle managing human development and human interaction, in union with other, accompanying,

46 E. Cassirer, op. cit., p. 85.

47 See: E. Gans, The Origin of Language..., op. cit., p. 41.

${ }^{48}$ M. Lauschke, 'Representation' and 'Presence' in the Philosophy of Ernst Cassirer, [in:] Ernst Cassirer on Form and Technology, eds. A.S. Hoel, I. Folkvord, London 2012, p. 182.

49 More recently, Gans has applied the term 'symbol' to discuss the idea of the 'scene'; see: E. Gans, The New Origin of Language, Part 3: The Ostensive, "Chronicles of Love and Resentment”, No. 537, 25.02.2017, http://anthropoetics. ucla.edu/views/vw537/ [accessed 15.03.2020].

${ }^{50}$ Idem, Originary Thinking..., op. cit., p. 2.

${ }^{51}$ German original: Philosophie der symbolischen Formen. Erster Teil: Die Sprache, Berlin, 1923. 
symbolic forms governing the human world (e.g. myth, religion), equal in status and level ${ }^{52}$. Gans, however, declares language the privileged formal criterion of humanity and notes that the scene of origin obliges us to define human beings as users of language primarily. Cassirer's language is a primordial expression of human spiritual energy, of human spontaneity in the building up of an objective world, but as pure form ${ }^{53}$, albeit far from reflecting the basic reality or having the ability to become a center of culture, as it is for Gans, who even comes to the conclusion that 'humanity = language' ${ }^{54}$. Also for Cassirer, language is an independent, cultural symbolic form, with its specific underlying law $^{55}$, but unreservedly functional ${ }^{56}$.

Cassirer's symbolic forms are expressions of knowledge. Gans's language is the birthplace of knowledge, mainly because it is the instrument of self-knowledge of the community that used it for the first time ${ }^{57}$. From this knowledge it is only one step to the consciousness and cognition Cassirer refers to in the context of the comprehension of the symbol. Cassirer's inquiry seeks first of all, after a rule governing the 'source' of symbolic forms and the concrete diversity of functions of cognition, a rule which, without negation and destruction, will gather them ,into a unity of deed, a unity of a self-contained human endeavor"58. Moreover, Cassirer argues that cognition „aims ultimately at subjecting the multiplicity of phenomena to the unity of the "fundamental proposition " " many times, but he does not assign it as much importance as Cassirer. He is

52 E. Cassirer, op. cit., p. 71-77.

53 Ibidem, p. 71.

54 E. Gans, Originary Thinking..., op. cit., p. 2.

${ }_{55}$ E. Cassirer, op. cit., p. 71.

56 John M. Krois argues, that Cassirer's fundamental conception of symbolism ('symbolic pregnancy') derives rather from a bio-medical model of semiotics, based on 'natural symbolism' of image-like configurations in body feeling and perception, than from a linguistic one, as purely arbitrary and conventional; see: J.M. Krois, Cassirer's 'Prototype and Model' of Symbolism: Its Sources and Significance, „Science in Context" 1999, Vol. 12, No. 4, p. 531.

57 E. Gans, Originary Thinking..., op. cit., p. 2.

${ }^{58}$ E. Cassirer, op. cit., p. 77.

59 Ibidem. 
aware of the function of cognition in the scene, however, he does not develop this thread, but rather indicates it as another issue worth exploring through GA. Cassirer, though, argues that every authentic function of the human spirit possesses a decisive characteristic in common with cognition, which embodies an original, formative power and results in symbolic forms. Therefore, the formative power of cognition is of top importance ${ }^{60}$. This process is not passive, but signifies the potential of energy of the human spirit through which phenomena assume a definite 'meaning' and a particular ideational content ${ }^{61}$, its self-revelation ${ }^{62}$, not to reflect empirically a given world ${ }^{63}$, but to produce it according to an independent principle. Also, cognition conceives of physical phenomena as transcending the world of sensory experience. Cognition and sensory data do not correspond to each other $^{64}$, because the conceptual world of physics is entirely self-contained ${ }^{65}$. Gans, too, points out that his model of the originary event left no physical

60 Ibidem, p. 78.

${ }^{61}$ Ibidem. It should be also noted that the concept of 'ideational' was incorporated into the theory of cognitive anthropology formulated much later by Ward Hunt Goodenough; see: idem, Cultural Anthropology and Linguistics, [in:] Report of the Seventh Annual Roundtable Meeting on Linguistics and Language Study, ed. Paul L. Garvin, Washington (DC) 1957; idem, Culture, Language and Society, Reading (Mass) 1971.

62 E. Cassirer, op. cit., p. 78.

63 That is, differently from contemporary cognitive postulates (see for example: F.C. Bartlett, Remembering: A Study in Experimental and Social Psychology, Cambridge 1932; G. Lakoff, M. Johnson, Metaphors We Live By, Chicago 2003; F.J. Varela, E. Rosch, E. Thompson, The Embodied Mind. Cognitive Science and Human Experience, Boston 1992). However, in an earlier work Substance and Function, Cassirer speaks of the effect of experience on cognition (see: S. Matherne, Cassirer's Psychology of Relations, „Journal for the History of Analytical Philosophy” 2018, Vol. 6, No. 3, p. 138, 141).

${ }^{64}$ This position is the opposite of contemporary cognitive research findings. See. R.G. D'Andrade, Memory and Assessment of Behavior. In Measurement in the Social Sciences, ed. T. Blalock, Chicago 1974, p. 159-186; idem, The Development of Cognitive Anthropology, Cambridge 1995; G. Lakoff, M. Johnson, op. cit.

${ }^{65}$ E. Cassirer, op. cit., p. 85. 
traces, although he speaks of its mental traces that are coextensive with the human cultural universe ${ }^{66}$.

Cassirer presupposes the original act of the human spirit as the base for all components of culture subjected to the universal rule. On this level Gans proposes an event which does not have links with a spiritual origin, but with the human ability to initiate a process of self-presentation, conditioned by the nature of human existence. Gans forms a hypothetical scene of the origins of representation while Cassirer does not, rather speaking of the source of language, directly relating language to cognition. This leads him to seek to understand the function of linguistic thinking, together with the function of mythical and religious thinking, as well as the function of artistic perception. In speaking of 'various products of culture', Cassirer sees language as fundamental, but not building 'human as human' - which is Gans's basic idea. Cassirer argues that language is accompanied by different parts of 'the single great problem - complex' such as: scientific knowledge, myth, art, religion; however, he does not assign a privileged position to the language. Cassirer sees them all „directed toward the one goal of transforming the passive world of mere impressions, in which the spirit seems at first imprisoned, into a world that is pure expression of the human spirit"67.

Cassirer's 'explicit' thoughts about language, which are of particular importance to GA were included in other texts as well. His last lecture seems particularly significant. It shows that Cassirer had been seduced by the newly emerging structuralism ${ }^{68}$. He situated language in opposite ways of thinking: structuralistic versus mechanistic, or morphological versus materialistic. After an argumentation based initially on a philosophical diachronic analysis, he came to the following conclusion: „language is neither a mechanism nor an organism”; „not a thing at all”; a „very specific human activity, not describable in terms of physics, chemistry, or biology”; „»organic«, but not an »organism “" , it can't be put at the same level as plants and animals"69. In this way Cassirer demonstrates the battle between the biological and

${ }^{66}$ E. Gans, Science and Faith..., op. cit., p. 4.

${ }^{67}$ E. Cassirer, op. cit., p. $80-81$

68 Idem, Structuralism in Modern Linguistics, „WORD” 1945, Vol. 1, No. 2, p. 109.

${ }^{69}$ Ibidem, p. 110 
the linguistic views, which finds a solution in Gans's understanding of language as a unique human property related to all enumerated dimensions. Cassirer doesn't stop there, however. In order to achieve his objective 'globus intellectualis' of knowledge - he moves to the issue of the relationship of language, speech and sound, three categories which are implicitly present in Gans's concept of GA, but in an 'originary' understanding. Let us recall that Gans always refers language to the originary event, an appearance of the first linguistic sign, an aborted gesture of appropriation, in the presence of its referents, without which it could not exist. Language takes precedence, starting with the 'originary ostensive' - a signal, then a sign emerging from the deferral of action in a situation of shared, joint attention ${ }^{70}$, in the collective presence of humans. The speech and sound from Cassirer's philosophy, placed in Gans's world, always belong to articulate language ${ }^{71}$ and need not to be distinctive categories of Gans's theory. They are linguistic forms, elementary as well as advanced. An event of language that constitutes 'human in his humanity', though, is an ontological moment of demonstration of the human's exceptional status. Gans's analises enter the ontology of language, linked to mechanisms of social functioning based on deferral of action.

Coming to Cassirer, we leave 'originary thinking' and note that Cassirer in speaking of linguistics places it in the area of the humanities [Geisteswissenschaft], not in the sense of a sharp opposition between metaphysics and 'matter', but in the sense of transition, from substantia extensa to substantia cogitans, where language is called a 'continuous miracle'. Hence, every speech act becomes for him 'a sort of transubstantiation', where speech is also meaning - an 'incorporeal thing' expressed in sounds (as material things). He comes to the conclusion that it is functional sense that solves the problem of building up the world of human culture rather than language, understood as a 'symbolic form' that consists of symbols, which are not a part of physical world, but belong to universe of discourse $\mathrm{e}^{72}$. This statement manifestly agrees with Gans's theory, that urges semiotics as a system of representation.

70 E. Gans, The New Origin of Language..., op. cit.

${ }^{71}$ Idem, The Origin of Language..., op. cit., p. 74.

72 E. Cassirer, Structuralism in Modern Linguistics, op. cit., p. 109-115. 


\section{GANS AND HEIDEGGER}

Moving on to Gans's references to Heidegger let's look again at the concept of language. Early, as well as late, Heidegger followed the trail of language in a multitude of contexts. We must note, however, that the main objective of Heidegger's fundamental ontology, an analysis of being as Being, does not place language in the center. This is what Gans does. Heidegger's famous expression that "language is the house of Being"73 is linked to the uniquely human capacity for language, which surpasses the abilities of other beings $^{74}$, known to us already from Cassirer and Gans. Heidegger stated openly that "the essence of man consists in language" 75 . This we recognize as one of Gans's basic assumptions, the idea that Gans has been proving since his first publication on GA, namely The Origin of Language, which is continued constantly.

We note that Heidegger, in his discourse on Being, constructed his own, original and specific terminology by rejecting traditional philosophical terms and using language somewhat closer to colloquial speech, often reaching for classical Greek notions to be near to the 'beginnings', which aligns him with Gans's heuristics. Moreover, Heidegger's Being can itself be interpreted as a language process ${ }^{76}$, which - going to another level becomes "the real center of human existence"77: continuous, holistic and universal ${ }^{78}$. According to Bambach, Heidegger's language as discourse uncovers an essential unity between language and an originary community

${ }^{73}$ M. Heidegger, Letter on Humanism, [in:] idem, Basic Writings, eds. and transl. F.A. Capuzzi, J.G. Gray, D. Farrell Krell, London 1993, p. 217.

74 Heidegger, as Pöggeler emphasizes, is fully convinced of the ontological distinctiveness of animals and humans (Otto Pöggeler, Droga myślowa Martina Heideggera, transl. B. Baran, Warszawa 2002, p. 300).

${ }^{75}$ M. Heidegger, The Way to Language, [in:] idem, On the Way to Language, transl. P. Hertz, New York 1971, p. 398.

${ }^{76}$ R.L. Król, Analiza kategorii bycia i człowieka w koncepcji filozoficznej Martina Heideggera, Truskaw 2017, p. 12.

77 Ibidem, p. 16.

78 Ibidem, p. 15-17. 
in an ontological relation ${ }^{79}$, on which Gans bases his concept of the scene of origin of language and culture.

Whereas Cassirer's language is still in a Kantian mode - a part of culture and the critique of reason - Heidegger wants to free language from the tyranny of logic and reason and he argues that feelings and moods may say more about the world than reason itself ${ }^{80}$. He considers language one of many tools accessible to a human, having limitations and thus he rejects an exclusive dependence on it $^{81}$. Undoubtedly, Heidegger also rejects Cassirer's vision of the transcendental symbolic as a system of representation. His core concepts, cumulating in his most significant publication, Being and Time (1927), which Theodore Kisiel calls 'clearing of being' ${ }^{82}$, deny the entire transcendental ego and build the concrete, historical and practical world, with reference to language, which is expressed as 'Being-in-the-world', with all concerns, plans and expectations, but not as an object of contemplation. Moreover, language derives from and determines the communal structure of Being-in-the-world ${ }^{83}$. Continuing an application of Heidegger's phenomenology to complement Gans's vision of a person manifesting his humanity in the 'scene', we may state that Gans's 'scene' is parallel to Heidegger's 'being-with-the-others ' 84 , to 'particular being towards intra-worldly beings', to 'being-among intra-worldly beings' but not on the level on 'the basic constitution of the Dasein [Being] ${ }^{85}$.

Gans's 'scene' is communal mainly in a Durkheimian sense ${ }^{86}$ and as a form of 'being-with-others', especially in "the moment of the gesture of designation" as "the moment of formation of a human community, defined

79 Ch. Bambach, Heidegger's Roots. Nietzsche, National Socialism and the Greeks, Ithaca - London 2003, p. 62.

${ }^{80}$ L. Braver, Heidegger, Cambridge 2014, p. 2.

81 Ibidem.

82 Th. Kisiel, The Genesis of Heidegger's 'Being and Time', Berkeley - Los Angeles - London 1993, p. 377.

83 S. Mulhall, Heidegger and 'Being and Time', London - New York 2005, p. 89.

${ }^{84}$ M. Heidegger, The Basic Problems of Phenomenology, Bloomington Indianapolis 1988, p. 278.

85 Ibidem.

${ }^{86}$ E. Gans, The End of Culture..., op. cit., p. 89. 
by the collective presence of its members" ${ }^{\prime 8}$. However, giving the floor directly to Gans, we can see that he constantly confirms coming to 'being-with-others' as a form of the originary communal event. Regardless of Heidegger's words that „being-alone is a form of being-with”, Gans pays particular attention to Heidegger's fundamental belief that "Dasein clearly shows that "first of all" this being is unrelated to others" ${ }^{88}$. In his subsequent comments Gans goes even further, saying that „human consciousness without language or language without society is an ontological absurdity" He repeats constantly that the human does not come to being-with-others from an individual experience: „We come to those experiences as a »withdrawal " from the originary communal scene" and continues by noting that Heidegger's being-alone is a form of being-with. Yet, he sees a crucial difference: Heidegger's being-with cannot become the matrix for human culture because of Dasein's fundamental, yet not existential individuality. Moreover, he points out that even Heidegger's discussion on language as 'speech' doesn't explain the main question posed - the origin of language ${ }^{90}$.

However, for Heidegger, primary being is revealed in speech (Rede $)^{91}$, which is exposed in language. Also, in view of Gans's concept of the 'ostensive ${ }^{29}$, Heidegger's understanding of language as seeking association via speech proves its existential and ontological foundation ${ }^{93}$. Furthermore, for him, speech is not only existential but also primal, as location and comprehension of a language, as an articulation of intelligibility, though finally and existentially it is a language ${ }^{94}$. In his lecture, Ontology, Heidegger claims that the concept of a 'human' defined as a 'being endowed with reason' does not agree with the decisive sense of the Greek classical philosophy by Aristotle

87 Ibidem, p. 46.

${ }^{88}$ Idem, On 'Being and Time', op. cit.

89 Ibidem.

90 Ibidem.

${ }_{91}$ Ibidem. It should be noted, however, that in Being and Time, Heidegger starts from the concept of the Greek $\lambda$ óyoc, translated as 'discourse' in: M. Heidegger, Being and Time, transl. J. Macquarrie, E. Robinson, Oxford 2001, p. 55.

92 See above all: idem, The Origin of Language..., op. cit., p. 68-98.

93 M. Heidegger, Being and Time, op. cit., p. 209-210.

94 Ibidem, p. 204. 
and his comprehension of Logos. Heidegger says that Logos never means 'reason' but 'speech' and 'conversation', and that a human is a being „who has his own world in a way of something accosted"95. His thought is known for presenting speech as a "home for the truth of being" 96 where he again demonstrates language to be the primary place for Being, as its foundation.

In line with Gans's thinking, who speaks about „making the effort to conceive the human in universal terms" ${ }^{\prime 7}$, we follow his final conclusion that „all thinking is originary analysis"98. We note Heidegger's argument that thinking and Being do not oppose each other, reflecting on the famous Parmenidean question concerning the relation of 'being and thinking', where Heidegger himself warns against their separation ${ }^{99}$. Being and thinking have their references, as presented in the above paragraphs, in the core concept of GA - the scene of origin, whose existence is constitutive. To capture Heidegger's Being in the Gansian scene, we have to move from thinking to understanding and approach the sense of originary thinking by turning towards its causal interpretation. Heidegger's Being is focused on being itself, which is "thrown into conditions it did not create”, which results in the fact that Being is 'entangled' in the world as it is „bound up in its destiny" 100 . Gans's human, too, is openly entangled in the world, the world which Gans describes as a sequence of scenic events, and which consist of other beings with their rivalry for central objects. Heidegger's question: what makes the 'sense of being' ${ }^{101}$, with its response that 'Being makes sense of being by choosing a way of being'102 illustrates Gans's concept of the human who chooses the signs instead of violence. For us it is an effect of the understanding attributed by Heidegger to Being. Heidegger

95 Idem, Ontologia (Hermeneutyka faktyczności), eds. S. Czerniak, N. Leśniewski, J. Rolewski, transl. M. Bonecki, J. Duraj, Toruń 2007, p. 28.

96 Idem, Letter on Humanism, op. cit.

97 E. Gans, Originary Thinking..., op. cit., p. VII.

98 Idem, Signs of Paradox..., op. cit., p. 98

99 Ch. Bambach, op. cit., p.147-148.

100 M. Heidegger, Being and Time, op. cit., p. 82.

101 Ibidem, p. 21.

102 See: ibidem, p. 33, 313, 377. 
explains understanding as "the basic determination of existence"103; what is more, he maintains that „to exist is [...] to understand" 104 . In reference to Gans's human, understanding of the world means, as discussed above, the appearance of the aborted gesture of appropriation, its turn into a gesture of designation ${ }^{105}$, and their final result, namely, a deferral of violence. Furthermore, Heidegger states that understanding is a condition for both cognitive and practical comportment, so the emission of a sign (in a form of gesture or sound) is not only an expression of understanding, but also of comprehending the world, as one might suggest, again related to the deferral of violence.

We have to note that the subject of violence is not alien to Heidegger. The topic itself may be considered controversial, not because of the issues analyzed here, but because of the political context of Heidegger's attitude ${ }^{106}$. Interpreting Heidegger, Bambach indeed claims that for Heidegger violence is of the essence, of being itself ${ }^{107}$. Therefore Heidegger's statements that human is a 'violence-doer' ${ }^{108}$, in the sense of 'the one who needs to use violence', and „using violence is the basic trait not only of his doing but also of his Dasein [Being] [...]"109, confirm Gans's theory of potential violence on the 'human scene'. Further, Gans talks about the existence of potential violence, putting it at the level of the deepest justifications of the scene of origin; however, in the context of desire and appetite always being present in human life. Moreover, if the essence of being is itself violent, as Heidegger maintains, and only understanding and experience can unfold the being, Gans's 'scene'

103 Idem, The Basic Problems of Phenomenology, op. cit., p. 278.

104 Ibidem, p. 276.

105 E. Gans, The End of Culture..., op. cit., p. 14.

106 We are obliged to add here that Heidegger's interest in the issue of violence was also political and has been widely commented upon, bringing him infamy regarding the issue of National Socialism (see: Ch. Bambach, op. cit., p. 146-152; C. Wodziński, Metafizyka i metapolityka. Czarne zeszyty Heideggera, Gdańsk 2016). This problem, however, is not the subject of our reflection here.

107 Ch. Bambach, op. cit, p. 150.

108 M. Heidegger, Introduction to Metaphysics, transl. R. Manheim, New Haven 1959, p. 149.

109 Ibidem, p. 151. 
is a form and at the same time a way to 'unfold the being', because it is an expression of understanding of the human condition and an expression of human experience as overcoming violence, by its deferral in the aborted gesture of appropriation and designation of an already known to us object, bringing it up to the level of representation. Therefore, using Heidegger's abovementioned thoughts, we may find justification for Gans's statement that „the heart of culture is the deferral of violence through representation"110. It is interesting to note that Bambach, finding in Heidegger's discourse a heuristics similar to Gans's, notices the „tension within the definition of human being between his violence-doing against being and the violence of being itself" and pays attention to Heidegger's vision of the „uncanny condition of human existence upon the earth"111, which one might take to also refer to the scene of origin.

Although the topic of violence is present in Heidegger's discourse, there is another related issue to which he devotes more attention. It is the concept of anxiety ${ }^{112}$, that we regard as a complement of Gans's understanding of violence. It remained central to Heidegger's thought, early and later alike. Heideggerian anxiety is one of Being's basic possibilities of being, a "distinctive way in which Being is disclosed"113. From the point of view of Gans's scene, it could constitute the effect of consciousness of the existence of intra-human violence expressed by „the original aborted gesture, motivated by the common fear of violence"ll4. However, Heidegger approaches these topics in a phenomenal analysis ${ }^{115}$ and does not translate them into an event, such as the scene of origin, an example of existential activity. As Król explains, anxiety is a fear of not being, a fear of death ${ }^{116}$, a credible reference to being as having its 'end'117, which substantiates that fear ${ }^{118}$. Like

\footnotetext{
110 E. Gans, The End of Culture..., op. cit., p. 147.

111 Ch. Bambach, op. cit., p. 151.

112 M. Heidegger, Being and Time, op. cit., p. 227.

113 Ibidem., p. 228.

114 E. Gans, The End of Culture..., op. cit., p. 47.

115 M. Heidegger, Being and Time, op. cit., p. 78-79, 87, 107.

116 R.L. Król, op. cit., p. 200.

117 Ibidem, p. 197.

118 M. Heidegger, Being and Time, op. cit., p. 179.
} 
anxiety, fear is a mode of 'being of Being'119 and both are a 'mode of stateof-mind' ${ }^{120}$. In this configuration, the issue of violence is accompanied by the issues of anxiety and of fear mentioned above. In Heidegger's thought they express the basic possibilities of Being. But Heidegger does not indicate any 'solution' to overcome their presence, in the way Gans does, that is, by moving to the human, existential level defined by the 'scene'. Heidegger therefore remains at the initially assumed ontological level as an announcement of a state of Being. In this view, Gans's concept becomes an applied ontology of language and culture as a unique human existential potential.

\section{CONCLUSIONS}

The present paper attempts to place GA, a model of origin of language and culture as a communal event, which Gans has also called a 'new way of thinking', in the context of Cassirer's and Heidegger's extensive and multidimensional concepts of the human and his being. With the passage of time, the scope of understanding of their concepts expands, making it possible to bring them into a dialogue with GA. The paper has focused on Cassirer and Heidegger's thought in terms of the way their thought bears on the subjects of language, sign, speech and violence, the ingredients of Gans's scene, understood as components of Gans's ontology applied to human's being in the world.

Cassirer's symbolic representation of human, and Heidegger's human as Being in the process of being, formed from two different vital Kantian schools, which lead to opposite consequences. Cassirer accepted a transcendent instance expressed in a system of symbols, which ensured human understanding in stressing the role of humans' cognitive properties, or, rather, the cognitive links, via symbols, connecting humans to the world. In this necessarily communal world, symbolic communication allows for recognition by the self of others. Heidegger, meanwhile, presented the individual's intentionality in response to the surroundings of Being, that is, being there, and stressed each person's input into the world. In what we could see as a synthesis of these opposing views, Gans's human can account for Cassirer's comprehension of cognitive properties of the human

119 Ibidem, p. 181, 183.

120 Ibidem, p. 172, 179-182. 
as the product of his active participation in the Heideggerian worldly universe. Moreover, Gans's language, meaning representation, corresponds to Cassirer's concept of a symbolic system questioned by Heidegger. Going to a more detailed level, and regarding what we said above, let us notice that Cassirer's sign serves not only to communicate a complete and given thought content, but is also an instrument by means of which this content develops, fully defines itself, and through its existence, as Gans helps us to say, enables humans to defer potential violence and crisis.

The deepest causes of the scene of origin are connected with this potential intra-human violence, to which Heidegger devotes a lot of attention and which is complemented by his concept of anxiety and fear which broadens the context of Gans's originary scene. To sum up, Gans's scene needs both Cassirer's and Heidegger's approaches to enable the human to surmount the intra-human crisis, which might hopefully be fostered by essays like this one, itself a linguistic act.

\section{Bibliography}

Roy G. D'Andrade, Memory and Assessment of Behavior. In Measurement in the Social Sciences, ed. T. Blalock, Aldine - Atherton, Chicago 1974.

Roy G. D’Andrade, The Development of Cognitive Anthropology, Cambridge University Press, Cambridge 1995.

Charles Bambach, Heidegger's Roots. Nietzsche, National Socialism and the Greeks, Cornell University Press, Ithaca - London 2003.

Andrew Barash, The Symbolic Construction of Reality. The Legacy of Ernst Cassirer, University of Chicago Press, Chicago - London 2008.

Frederic C. Bartlett, Remembering: A Study in Experimental and Social Psychology, Cambridge University Press, Cambridge 1932.

Lee Braver, Heidegger, Polity Press, Cambridge 2014. Ernst Cassirer, An Essay on Man, Yale University Press, New Haven 1944.

Ernst Cassirer, Structuralism in Modern Linguistics, „WORD” 1945, Vol. 1, No. 2. Ernst Cassirer, The Philosophy of Symbolic Forms, vol. 1: Language, transl. R. Manheim, Ch.W. Hendel, Yale University Press, New Haven 1965.

Eric Gans, A GA Cogito and other philosophical reinterpretations, „Chronicles of Love and Resentment”, No. 63, 28.09.2019, http://anthropoetics.ucla.edu/ views/vw633/. 
Eric Gans, A New Way of Thinking: Generative Anthropology in Religion, Philosophy, Art, The Davies Group, Aurora 2011.

Eric Gans, On 'Being and Time', „Chronicles of Love and Resentment”, No. 226, 20.01.2001, http://anthropoetics.ucla.edu/views/vw226/.

Eric Gans, Originary Thinking. Elements of Generative Anthropology, Stanford University Press, Stanford 1993.

Eric Gans, Science and Faith. The Anthropology of Revelation, Rowman and Littlefield Publishers, Savage 1990.

Eric Gans, Signs of Paradox, Irony, Resentment, and Other Mimetic Structures, Stanford University Press, Stanford 1997.

Eric Gans, The End of Culture. Toward a Generative Anthropology, University of California Press, Berkeley - Los Angeles - London 1985

Eric Gans, The New Origin of Language, Part 3: The Ostensive, „Chronicles of Love and Resentment", No. 537, 25.02.2017, http://anthropoetics.ucla.edu/views/ vw537.

Eric Gans, The Origin of Language. A Formal Theory of Representation, University of California Press, Berkeley - Los Angeles - London 1981 (2019).

Eric Gans, The Scenic Imagination. Originary Thinking from Hobbes to the Present Day, Stanford University Press, Stanford 2008.

René Girard, Des choses cachées depuis la fondation du monde, Grasset, Paris 1978. René Girard, La Violence et le sacré, Grasset, Paris 1972.

Ward Hunt Goodenough, Cultural Anthropology and Linguistics, [in:] Report of the Seventh Annual Roundtable Meeting on Linguistics and Language Study, ed. P.L. Garvin, Georgetown University, Washington (DC) 1957.

Ward Hunt Goodenough, Culture, language and society, Addison - Wesley, Reading (Mass) 1971.

Charles, B. Guignon, Introduction, [in]: The Cambridge Companion to Heidegger, ed. Ch.B. Guignon, Cambridge University Press, Cambridge 1993.

Peter E. Gordon, Continental Divide: Heidegger, Cassirer, Davos, Harvard University Press, Cambridge (MA) 2012.

Martin Heidegger, Being and Time, transl. J. Macquarrie, E. Robinson, Oxford University Press, Oxford 2001.

Martin Heidegger, Introduction to Metaphysics, transl. R. Manheim, Yale University Press, New Haven 1959.

Martin Heidegger, Letter on Humanism, [in:] idem, Basic Writings, transl. F.A. Capuzzi, J.G. Gray, ed. D.F. Krell, Routledge, London 1993. 
Martin Heidegger, Odczyty i rozprawy, transl. J. Mizera, Wydawnictwo Aletheia, Warszawa 2007.

Martin Heidegger, Ontologia (Hermeneutyka faktyczności), transl. M. Bonecki, J. Duraj, eds. S. Czerniak, N. Leśniewski, J. Rolewski, Wydawnictwo Rolewski, Toruń 2007.

Martin Heidegger, The Basic Problems of Phenomenology, Indiana University Press, Bloomington - Indianapolis 1988.

Dell Hymes, Language in Culture and Society: A Reader in Linguistics and Anthropology, Harper \& Row, New York 1964.

Immanuel Kant, Critique of Pure Reason, transl. and eds. P. Guyer, A. Wood, Cambridge University Press, Cambridge 1998

Theodor Kisiel, The Genesis of Heidegger's 'Being and Time', University of California Press, Berkeley - Los Angeles - London 1993

John Micheal Krois, Cassirer's 'Prototype and Model' of Symbolism: Its Sources and Significance, "Science in Context” 1999, Vol. 12, No. 4

Marion Lauschke, 'Representation' and 'Presence' in the Philosophy of Ernst Cassirer,

[in:] Ernst Cassirer on Form and Technology, eds. A.S. Hoel, I. Folkvord, Palgrave Macmillan, London 2012.

Remigiusz Lucjan Król, Analiza kategorii bycia i człowieka w koncepcji filozoficznej Martina Heideggera, Wydawnictwo Naukowe SUB Lupa, Truskaw 2017.

George Lakoff, Mark Johnson, Metaphors We Live By, University of Chicago Press, Chicago 2003.

Marina Ludwigs, From de Man to Gans: The Return of the Referent, „Anthropoetics” 2018, Vol. XXIII, No. 2 (Spring).

Marina Ludwigs, Three Gaps of Representation / Three Meanings of Transcendence, "Anthropoetics” 2018, Vol. XV, No. 2 (Spring).

Samantha Matherne, Cassirer's Psychology of Relations, „Journal for the History of Analytical Philosophy" 2018, Vol. 6, No. 3.

Stephen Mulhall, Heidegger and 'Being and Time', Routledge, London - New York 2005.

Charles S. Peirce, The Essential Peirce. Selected Philosophical Writings, Vol. 1-2, Indiana University Press, Bloomington - Indianapolis 1992-1998.

Otto Pöggeler, Droga myślowa Martina Heideggera, transl. B. Baran, Czytelnik, Warszawa 2002.

Richard Schechner, Performance Theory, Routledge, London - New York 2003. Victor Turner, The Anthropology of Performance, PAJ Publications, New York 1988. 
Cezary Wodziński, Metafizyka i metapolityka. Czarne zeszyty Heideggera, Fundacja Terytoria Książki, Gdańsk 2016

Francisco J. Varela, Eleanor Rosch, Evan Thompson, The Embodied Mind. Cognitive

Science and Human Experience, The MIT Press, Boston 1992.

Magdalena Złocka-Dąbrowska, Generative Anthropology's Scene of Origin in Cognitive and Axiological Contexts, „Anthropoetics” 2019, Vol. XXIV, No. 2 (Spring), http://anthropoetics.ucla.edu/ap2402/2402mzd/.

\section{GA Among Giants. Gans's Scene of Language and Culture Origin in Reference to Cassirer's and Heidegger's Visions of the Human}

This essay situates Eric Gans's Generative Anthropology (GA) within Ernst Cassirer's and Martin Heidegger's intricate ontologies and validates GA as an applied ontology of language and culture. First, I will follow Gans's suggestions for placing GA within a philosophical context, in particular, in terms of his situating of GA as a response to Heidegger's Being and Time. I will then present Gans's central concept of GA - the rise of language/ culture as the origin of the 'human as human' - a way of linking Gans's system of representation with Cassirer's system of symbolic forms. The description of the main components of Gans's 'scene', namely: language, sign, community and violence, as responding to Cassirer's and Heidegger's respective understandings, will lead us to symbolic representation as opposed to a phenomenology that views forms merely as limitations for Being. I propose a mediating position between the competing claims of Cassirer and Heidegger, respectively, in Gans's originary thinking, in the 'explosion of language' that allows the hermeneutics of the language of being (Dasein) to regain its presence.

Keywords: Eric Gans, GA, Cassirer, Heidegger, scene of origin, representation, language, culture 